\title{
PERILAKU CELEBRITY WORSHIP PADA ANGGOTA FANDOM EXO DALAM KOMUNITAS EXO-L BANDUNG
}

\author{
Nadhifa Arundati, Almira Alda Vania, Melisa Arisanti \\ Universitas Pembangunan Jaya
}

\begin{abstract}
ABSTRAK
Merebaknya Hallyu di negara-negara Asia Timur dan beberapa negara Asia Tenggara termasuk Indonesia telah menunjukkan adanya aliran budaya dari Korea ke negara-negara tetangganya. Dalam situasi dunia dimana pertukaran informasi terjadi hampir tanpa halangan apa pun, Korea telah menjejakkan pengaruhnya di kawasan Asia. Sejarah K-Pop dimulai dengan munculnya boyband maupun girlband terkemuka, antara lain EXO, TVXQ, Se7en, Lee Hyori, Shinhwa, Wonder Girls, Epic High, Super Junior, Big Bang, SS501, sampai Girls' Generation. Daya tarik $K$-Pop dapat ditemukan dalam lagu, tarian, dan efek panggung yang besar, serta tempo cepat ala pop Korea dicampur dengan irama Asia yang sangat menarik untuk remaja termasuk Indonesia. Saat ini, boyband yang sedang populer dan memiliki banyak penggemar atau fans adalah EXO. Sebutan fans EXO adalah EXO-L yang tercatat sebagai fandom terbesar di dunia dengan jumlah fans yang melebihi angka 3 juta orang. Perilaku fans K-pop ini mengacu pada setiap komponen dari perilaku celebrity worship, dimana dalam perilaku ini terdapat beberapa faktor, aspek dan tahap yang mendukung perilaku pemujaan ini muncul.
\end{abstract}

Kata-kata Kunci: Hallyu, K-Pop, Boyband EXO, EXO-L, Celebrity Worship

\begin{abstract}
The rise of Hallyu in East Asian countries and several Southeast Asian countries including Indonesia has shown the flow of culture from Korea to neighboring countries. In a world situation where information exchange occurs almost without any hindrance, Korea has set its influence on the Asian region. The history of K-Pop began with the emergence of prominent boy and girl groups, including EXO, TVXQ, Se7en, Lee Hyori, Shinhwa, Wonder Girls, Epic High, Super Junior, Big Bang, SS501, to Girls' Generation. The charm of K-Pop can be found in songs, dances, and large stage effects, as well as the fast tempo of Korean pop style mixed with Asian rhythms which are very interesting for teenagers including in Indonesia. Currently, the boy band that is popular and has many fans is EXO. The name EXO fans is EXO-L which is listed as the biggest fandom in the world with a number of fans exceeding 3 million. The behavior of K-pop fans refers to each component of the behavior of celebrity worship, where in this behavior there are several factors, aspects and stages that support this worship behavior emerge.
\end{abstract}

Keywords: Hallyu, K-Pop, Boyband EXO, EXO-L, Celebrity Worship

\section{PENDAHULUAN}

Fenomena Hallyu ini mulai menerpa Indonesia pada tahun 2002 dengan maraknya drama seri Korea seperti Endless Love. Merebaknya Hallyu di negara-negara Asia
Timur dan beberapa negara Asia Tenggara termasuk Indonesia. Sejarah K-Pop dimulai dengan munculnya boyband yang beranggotakan tiga orang seperti: Seo Taiji dan Boys pada tahun 1992, dan beberapa 
nama boy band maupun girl band yang sedang naik daun saat ini, antara lain EXO, TVXQ, Se7en, Lee Hyori, Shinhwa, Wonder Girls, Epic High, Super Junior, Big Bang, SS501, sampai Girls' Generation. Daya tarik K-Pop dapat ditemukan dalam lagu, tarian, dan efek panggung yang besar, serta tempo cepat ala pop Korea dicampur dengan irama Asia yang sangat menarik untuk remaja termasuk Indonesia (Korea.net, 2012).

Data Korean Tourism Organization menyebutkan sebagian besar peminat hallyu tertarik oleh budaya musik K-Pop yakni sebesar 53,3\%, sedangkan untuk penggemar Film sebesar 6,2\%, TV Drama sebesar $33,2 \%$, dan lainnya hanya sebesar $7,1 \%$. Hal ini menunjukan bahwa penggemar budaya korea dalam hal K-pop sangat menguasai dibanding entertaiment yang disuguhkan oleh Korea. Dalam survey ini menunjukkan bahwa penggemar hallyu lebih dominan di usian 20-an yakni sebesar 40\% dibanding dengan usia lainnya. Jenkins mengatakan bahwa para penggemar adalah pemburu yang ingin menghaslkan apa yang mereka butuhkan dan menggunakan barang-barang ramapsan mereka sebagai fondasi bagi pembangunan sebuah komunitas kultural alternatif yang artinya para penggemar adalah suatu subcultural dalam pertentangannya dengan nilai-nilai dan norma-norma kehidupan sehari-hari, merasakan secara lebih intens, bermain dengan lebih bebas, dan berpikir lebih mendalam (Jenkins, Henry, 2017).

Saat ini, boyband yang sedang populer dan memiliki banyak penggemar atau fans adalah EXO (Lastriani, 2018). Fans EXO tersebut bernama EXO-L. EXO-L diresmikan lewat situs exo-1.smtown.com pada tanggal 05 Agustus 2014. Letter 'L' merupakan singkatan dari kata LOVE yang berarti EXO mencintai para penggemarnya. Pada 2016, fans kingdom (fandom) EXO atau yang disebut EXO-L berhasil mencatatkan diri di Guinness Book of World Records sebagai fandom dengan jumlah terbesar tahun 2016. Tahun 2017, EXO-L tercatat sebagai fandom terbesar di dunia dengan jumlah fans yang melebihi angka 3 juta orang (Sari, 2017).

Perilaku fans K-pop ini mengacu pada setiap komponen dari perilaku celebrity worship, dimana dalam perilaku ini terdapat beberapa faktor, aspek dan tahap yang mendukung perilaku pemujaan ini muncul. Dari setiap aksi yang dilakukan oleh para fans K-Pop tentu menggambarkan setiap komponen dari perilaku celebrity worship (Ulfianti 2012).

\section{TINJAUAN PUSTAKA}

\section{Tradisi Fenomenologi}

Tradisi Fenomenologi merupakan bagian dari teori komunikasi yang melihat proses komunikasi dari sudut pndang filsafat. Tradisi fenomenologi mengarah kepada komunikasi yang efektif - yakni sebagai dialog yang disertai dengan nilai keterbukaan dan otentitas baik dalam ucapan maupun tindakan. Tradisi fenomenologi digunakan untuk menganalisa komunikasi dalam rangka mencari kesalahpahaman yang terjadi dan melihat bagaimana kesalahpahaman tersebut dikoreksi oleh masyarakat secara 
keseluruhan. Tradisi ini mengasumsikan bahwa orang-orang secara aktif menafsirkan apa yang terjadi di sekitar mereka dan berusaha untuk memahami dunia melalui pengalaman pribadi. Dengan demikian tradisi Fenomenologi mengkaji pengalaman sadar manusia dan cara mengalaminya (Craig, 2016).

\section{Komunikasi Kelompok}

Michael Burgoon dan Michael Ruffner dalam bukunya: Human Communication, A Revision of Approaching Speech/Communication, memberi batasan komunikasi kelompok sebagai interaksi tatap muka dari tiga atau lebih individu guna memperoleh maksud atau tujuan yang dikehendaki seperti berbagi informasi, pemeliharaan diri atau pemecahan masalah sehingga semua anggota dapat menumbuhkan karakteristik pribadi anggota lainnya dengan akurat (Sendjaja, 2015).

\section{Fanatisme dan Fandom}

Fanatisme menurut Orever adalah antusiasme yang berlebihan dan tidak rasional atau pengabdian kepada suatu teori, keyakinan atau garis tindakan yang menentukan sikap yang sangat emosional dan misinya praktis tidak mengenal batasbatas. Sedangkan melihat fanatisme sebagai suatu antusiasme pada suatu pandangan tertentu yang diwujudkan dalam intensitas emosi dan sifatnya ekstrim (Gooch, 2008).

Menurut Joli Jenson (dalam Storey, 2010: 157), Fandom adalah salah satu cara di mana khalayak dapat menjadi aktif dan berpartisipasi dalam mengkreasikan makna dari sebuah teks dalam media. Literatur mengenai kelompok penggemar selalu dicirikan (mengacu pada asal usul istilahnya) sebagai suatu kefanatikan yang potensial. Hal ini berarti bahwa kelompok penggemar dilihat sebagai perilaku yang berlebihan dan berdekatan dengan kegilaan. Jenson menunjukan dua tipe khas patologi penggemar individu yang terobsesi (biasanya laki-laki) dan kerumunan histeris (biasanya perempuan). Ia berpendapat bahwa kedua figur itu lahir dari pembacaan tertentu dan kritik atas modernitas yang tidak diakui dimana para penggemar dipandang sebagai simpton psikologis dari dugaan disfungsi sosial.

\section{Celebrity Worship}

Celebrity worship merupakan perilaku kaum awam yang seringkali menjadikan sosok selebriti seperti aktris, musisi, atlet, atau orang-orang yang mucul di acara televisi. Hal ini menandakan obsesi kita terhadap seorang selebriti dipengaruhi oleh media massa yang mengontrol pikiran kita, yang menghubungkan interaksi antara diri kita dengan sang idola secara tidak langsung (Levy, 2015).

Terdapat 3 tahapan celebrity worship menurut McCutcheon (2004), yaitu:

1. Entertainment-social: Tahap ini terjadi pada saat seorang individu merasa penting atau senang membicarakan sang idola dengan orang banyak, dan membicarakannya di depan orang-orang serta senang membiacarakan perihal 
tentang sang idola dengan orang yang juga mengidolakannya.

2. Intense-personal: Tahap ini terjadi ketika seorang individu merasa adanya ikatan khusus dengan sang idola dan juga dapat merasakan apa yang dirasakan atau yang di alami sang idola tersebut, dengan mencerminkan dimensi kepribadian neurositisme seperti tertekan, emosional, cemas dan moody.

3. Borderline-pathological: Tahap ini terjadi dimana seorang individu memiliki fantasi atau khayalan yang membuatnya memiliki kedekatan khusus dengan sang idola serta memiliki keyakinan jika pada saat dia mengalami kesusahan, sang idola akan datang dan menolong atau membantunya, dengan mencerminkan dimensi kepribadian psikotisme seperti impulsif, anti sosial, dan egosentris.

Faktor yang dapat mempengaruhi terjadinya celebrity worship (McCutcheon 2004 ), yaitu :

1. Usia: Celebrity worship pada umumnya terjadi pada remaja berusia 11 tahun hingga 17 tahun dan berkurang setelahnya.

2. Pendidikan: Celebrity worship biasanya dilakukan oleh orang-orang dengan tingkat inteligensi yang rendah.

3. Keterampilan sosial: Celebrity worship terjadi pada orang-orang dengan keterampilan sosial yang buruk dan melihat bahwa celebrity worship merupakan pengisi kekosongan yang terjadi dalam hubungan yang nyata.
4. Jenis kelamin: Laki-laki dan perempuan dapat menyukai idola dengan konteks yang berbeda namun intensitas untuk menyukai idola biasnya lebih tinggi di kaum perempuan.

5. Ras/etnis: orang kulit hitam di Amerika lebih mungkin menyukai idola kulit hitam dibandingkan dengan idola kulit putih begitu juga sebaliknya orang kulit putih Amerika lebih cenderung untuk menyukai idola kulit putih dibandingkan idola kulit hitam.

Terdapat tiga aspek dalam celebrity worship yakni antara lain:

1. Religiusitas: religiusitas adalah keseluruhan dari fungsi manusia yang meliputi keyakinan, perasaan, dan perilaku yang diarahkan secara sungguh-sungguh dan sadar pada ajaran agamanya. Aspek religiusitas pada faktor ini berhubungan dengan tingkatan religiusitas individu.

2. Body Image: Berdasarkan penelitian yang dilakukan oleh Maltby et al., (2005) bahwa celebrity worship juga dipengaruhi oleh body image. Seorang selebriti yang memiliki tubuh ideal biasanya menjadi tolak ukur bagi seorang penggemar untuk membentuk tubuh yang ideal seperti artis idolanya.

3. Kepribadian: Kepribadian disini diartikan sebagai perilaku individu atau penggemar yang terpengaruh oleh idolanya.

\section{Komunitas}

Merujuk pada penjelasan Tonnies dalam bukunya Community and Asociation, 
menjelaskan bahwa komunitas terbagi menjadi Gemeinschaft dan Gesellschaft. Gemeinshcaft merujuk pada jenis komunitas yang berkarakter dimana setiap individu maupun aspek sosial yang ada pada komunitas tersebut berinteraksi secara vertikal dan horizontal, berjalan dengan stabil dalam waktu yang lama, adalah hasil dari adanya pertukaran ritual maupun simbol-simbol sebagaimana yang terjadi dalam interaksi sosial secara nyata yang dibangun face-toface interaction.

\section{METODOLOGI PENELITIAN}

\subsection{Paradigma Penelitian}

Paradigma adalah suatu cara pandang untuk memahami kompleksitas dunia nyata. Paradigma tertanam kuat dalam sosialisasi para penganut dan praktisinya. Paradigma menunjukkan pada mereka apa yang penting, absah, dan masuk akal. Paradigma juga bersifat normatif, menunjukkan kepada praktisinya apa yang harus dilakukan tanpa perlu melakukan pertimbangan eksistensial atau epistemologis yang panjang (Mulyana, 2003: 9)

Pada aspek lain, paradigma akan memberikan rambu-rambu tentang apa yang harus dihindari dan tidak digunakan dalam penelitian. Menurut sebuah analisis yang dikutip dari Bogdan dan Biklen, paradigma merupakan kumpulan longgar dari sejumlah asumsi yang dipegang bersama, konsep atau proposisi yang mengarahkan cara berpikir dan penelitian (Hennink, 2011).

Dalam penelitian komunikasi yang berhubungan dengan kelompok, organisasi, ataupun masyarakat, peneliti interpretif berusaha untuk melakukannya dari perspektif mereka yang diteliti karena ingin mengetahui suara atau komunikasi yang terlibat pada level yang berbeda-beda termasuk interpersonal. Peneliti dengan paradigma ini akan melihat komunikasi yang dialami oleh manusia bukan sebagai suatu hal yang logis namun terbuka, kompleks dan manusiawi; juga melihat komunikasi dan hubungan sosial sebagai hal yang tak terpisahkan dari konteks sosial dan historis (Daymon and Holloway, 2011).

Dalam penelitian interpretif, peneliti tidak bisa netral atau seluruhnya obyektif. Oleh karena itu, pengalaman mereka sendiri dapat digunakan sebagai data. Dengan tidak adanya kerangka yang pasti sebelum penelitian dimulai, penelitian interpretif berjalan sesuai proses, dengan wawancara menggunakan panduan wawancara yang fleksibel. Wawancara mendalam yang dilakukan tidak ada standarnya dan partisipan memiliki kontrol. Sampel umunya kecil tapi menghasilkan data yang banyak. Hubungan antara peneliti dan yang diteliti dekat, idealnya berdasarkan posisi kesetaraan sebagai manusia. Para peneliti interpretif mengacu pada kriteria keaslian (authenticity) dan kepercayaan (trustworthiness) (Daymon and Holloway, 2011).

Penggunaan paradigma interpretif dalam penelitian ini merujuk kepada pemaknaan dan pemahaman mengenai perilaku celebrity worship yang dilakukan oleh suatu kelompok yaitu komunitas EXO-L 
Bandung serta bagaimana sudut pandang EXO-L Bandung terhadap boy band EXO.

\section{Metode Penelitian}

Pendekatan yang digunakan dalam penelitian ini adalah dengan menggunakan pendekatan kuantitatif. Menurut Sugiyono (2012:20)dalamRumaisa(2015)menjelaskan bahwa kuantitatif merupakan salah satu jenis penelitian yang spesifikasinya adalah sistematis, terencana, dan terstruktur dengan jelas sejak awal hingga pembuatan desain penelitiannya. Definisi lain menyebutkan penelitian kuantitatif adalah penelitian yang banyak menuntut penggunaan angka, mulai dari pengumpulan data, penafsiran terhadap data tersebut, serta penampilan dari hasilnya.

Penelitian pada hakikatnya merupakan suatu upaya untuk menemukan kebenaran atau untuk lebih membenarkan kebenaran. Penelitian kuantitatif adalah metode penelitian yang dapat menggambarkan atau menjelaskan suatu masalah yang hasilnya dapat digeneralisasikan. Dengan demikian tidak terlalu mementingkan kedalaman data atau analisis data. Peneliti lebih mementingkan aspek keluasan data sehingga data atau hasil riset dianggap representasi dari seluruh populasi (Wicaksono, 2015).

Peneliti menggunakan metode penelitian kualitatif. Penelitian kualitatif adalah metode-metode untuk mengeksplorasi dan memahami makna yang oleh sejumlah individu atau sekelompok orang dianggap dari masalah sosial atau kemanusiaan. Proses penelitian kualitatif melibatkan upaya-upaya penting, seperti mengajukan pertanyaan- pertanyaan dan prosedur-prosedur, mengumpulkan data yang spesifik dari para partisipan, menganalisis data secara induktif mulai dari tema-tema khusus ke tema-tema umum (Creswell, 2014:4-5).

Strategi penelitian kualitatif menurut John Creswell (2014) dalam bukunya yang berjudul "Research Design" menyatakan bahwa terdapat 2 fokus strategi penelitian kualitatif, yakni: (1) Survei yang artinya memaparkan secara kuantitatif, sikap ataupun opini dari suatu populasi. (2) Eksperimen menitikberatkan bahwa treatment tertentu akan mempengaruhi hasil dari suatu kelompok tertentu.

Strategi dalam penelitian ini menggunakan strategi fenomenologi. Dalam penelitian fenomenologi melibatkan pengujian yang teliti dan seksama pada kesadaran pengalaman manusia. Konsep utama dalam fenomenologi adalah makna. Makna merupakan isi penting yang muncul dari pengalaman kesadaran manusia. Untuk mengidentifikasi kualitas yang essensial dari pengalaman kesadaran dilakukan dengan mendalam dan teliti (Smith2009: 11).

\section{Unit Analisis}

Unitanalisismerupakansatuanunityang akan diteliti, bisa berupa individu, organisasi atau pihak-pihak lain yang memberikan respon terhadap perlakuan ataupun tindakan yang dilakukan peneliti dalam penelitiannya. Dalam sebuah penelitian, menentukan unit analisis diperlukan agar peneliti dapat mengetahui dan menentukan masalah dari penelitian tersebut. Strategi pemilihan 
informan dalam penelitian ini yakni dengan Criterion Sampling, yang merupakan teknik pengumpulan data informan sesuai dengan kriteria. Bentuk strategi ini mengacu pada sebuah informan yang memiliki kekayaan informasi terkait dengan sebuah kasus (Rhodes et al, 2003).

\section{Metode Pengumpulan Data}

Data kualitatif untuk pengumpulan data dibagi menjadi dua yaitu data primer dan data sekunder. Menurut Sugiyono (2010:137), sumber data primer adalah data yang diperoleh secara langsung meliputi dokumen-dokumen perusahaan berupa sejarah perkembangan perusahaan, struktur organisasi dan lain-lain yang berhubungan dengan penelitian, yaitu:

1. Wawancara Mendalam. Melalui wawancara secara mendalam (depth interview) peneliti bertujuan untuk mengumpulkan informasi yang kompleks, yang sebagian besar berisi pendapat, sikap, dan pengalaman pribadi. Peneliti dapat melakukan face-to-face interview Berikut masing-masing penjelasan dari pengumpulan data primer dan data sekunder.

2. Observasi: Suatu proses melihat, mengamati dan mencermati perilaku (yang tampak) secara sistematis untuk tujuan tertentu. Dalam hal ini peneliti memiliki peranan pengamat aktif, yaitu peneliti akan berbicara, bertanya, serta menggali informasi lebih dalam dengan narasumber.

3. Dokumen: Selain melalui wawancara dan observasi, informasi juga bisa diperoleh lewat fakta yang tersimpan dalam bentuk surat, catatan harian, arsip foto, hasil rapat, cenderamata, jurnal kegiatan dan sebagainya.

4. Focus Group Discussion: Metode terakhir untuk mengumpulkan data ialah lewat diskusi terpusat (Focus Group Discussion), yaitu upaya menemukan makna sebuah isu oleh sekelompok orang lewat diskusi untuk menghindari diri pemaknaan yang salah oleh seorang peneliti.

Data sekunder adalah data yang diperlukan untuk mendukung hasil penelitian berasal dari literatur, artikel dan berbagai sumber lainnya yang berhubungan dengan penelitian (Sugiyono, 2010:137).

\section{Metode Analisis Data}

Metode analisis data yang digunakan peneliti adalah dengan teknik coding. Salah satu langkah-langkah sistematis dalam menganalisis data dengan teknik coding Strauss dan Corbin dalam yaitu:

1. Open Coding adalah tahap dimana memungkinkan peneliti mengidentifikasi kategori-kategori dan dimensi-dimensinya

2. Axial Coding adalah tahap mengorganisasikan data melalui dikembangkannya hubungan-hubungan diantara kategorikategori.

3. Selective Coding adalah tahap terakhir dimana peneliti menyeleksi kategori yang paling mendasar, secara sistemis menghubungkannya dengan kategori lain dan memvalidasikan hubungan tersebut. 


\section{Metode Pengujian Data}

Penelitian kualitatif memiliki cara untuk menilai tingkat validitas suatu data dimana menurut John Creswell (2014) dalam bukunya "Research Design" membagi menjadi 7, yakni sebagai berikut:

1. Triangulasi yang artinya memeriksa bukti-bukti yang berasal dari sumber dan menjustifikasikannya ke dalam tema-tema yang koheren dan juga menambahkan penilaian keabsahan data dari beberapa partisipan yang mengetahui datanya.

2. Member checking yang artinya memberikan dan mendeskripsikan tema-tema penelitian kepada partisipan untuk melakukan kebenaran data kembali.

3. Rich and thick decription artinya adalah hasil dari penelitian bisa memberikan gambaran terhadap setting penelitian dari pengalaman partisipan.

4. Mengklarifikasi bias yakni dengan melakukan refleksi diri terhadap kemungkinan munculnya bias dalam suatu penelitian.

5. Menyajikan informasi yang berbeda atau negatif yang artinya perpektif ini tidak selalu menyatukan dan membahas informasi yang berbeda dan hal ini sangat mungkin menambah kredibilitas hasil penelitian.

6. Memanfaatkan waktu yang relatif lama dimana hal tersebut berguna untuk peneliti bisa memahami suatu fenomena yang diteliti.

7. Melakukan tanya jawab untuk meningkatkan keakuratan hasil penelitian. Da- lam penelitian ini, peneliti melakukan wawancara dengan informan menggunakan kategorisasi kunci yang telah dibuat peneliti agar mengajukan pertanyaannya sesuai dengan konsep penelitian.

8. Mengajak auditor untuk melakukan review ke seluruh proyek penelitian untuk memberikan penilaian objektif.

\section{HASIL DAN PEMBAHASAN}

\section{Informan Satu}

Informan satu dalam penelitian ini bernama Alfiana yang merupakan salah satu anggota EXO-L Bandung yang bekerja di perusahaan Telkom Indonesia, Jakarta ia sudah bekerja di perusahaan telkom selama dua tahun. Namun ia merupakan penduduk kota Bandung namun merupakan suku Batak. Alfiana sudah menjadi anggota EXO-L sejak tahun 2010 yakni saat ia menduduki bangku SMA di Bandung awalnya ia mengikuti komunitas tersebut karena mengikuti teman, lalu Alfiana mulai terpengaruh sampai menjadi terobsesi dan mengikuti perkembangan EXO.

Alfiana menjadi pemilihan informan dalam penelitian ini dikarenakan ia merupakan anggota aktif komunitas tersebut dengan memiliki tingkat pengetahuan yang tinggi terkait EXO, Alfiana mengetahui tentang bagaimana penjualan produk merchandise EXO, bagaimana tingkah fangirling di komunitas EXO-L Bandung bahkan ia juga suka mengetahui kontak personal manager EXO dan sejak SMA sudah sering menabung jika EXO digelar. 
Namun, dalam segi geografis, Alfiana mudah dijangkau untuk menjadi informan penelitian dikarenakan ia bekerja di kawasan Jakarta.

\section{Informan Dua}

Informan dua dalam penelitian ini bernama Inayah Bintang Utami adalah salah satu anggota EXO-L Bandung yang meupakan mahasiswa Universitas Indonesia jurusan Sastra Korea namun ia juga merupakan penduduk kota Bandung. Alasan Bintang mengambil Sastra Korea yakni ingin megetahui lebih dalam terkait kebudayaan Korea serta mempelajari bahasanya, hal ini berpacu pada boyband EXO yang ia gemari. Inayah Bintang menjadi pilihan informan dikarenakan bentuk pemujaan yang sangat tinggi kepada EXO khususnya dengan salah satu personil yakni D.O. Bintang merupakan anggota dari komunitas EXO-L yang rela melakukan segala hal demi boyband EXO. Peneliti memilih Bintang dikarenakan ia memiliki pengetahuan terkait EXO yang cukup tinggi serta pemujaan yang berlebihan di antara anggota EXO-L lainnya. Meski beberapa anggota EXO-L juga melakukan pemujaan yang tinggi, namun dari segi geografis, Inayah Bintang Utami juga mudah dijangkau dikarenakan lokasi kampusnya yang berkawasan di Depok.

\section{Informan Tiga}

Informan tiga dalam penelitian ini bernama Stella Amanda adalah salah satu anggota EXO-L Bandung yang merupakan mahasiswa Universitas Indonesia jurusan Kesehatan Masyarakat namun cita-citanya adalah sebagai musisi, ia memasuki jurusan Kesehatan Masyarakat akibat dari tuntutan orangtua, namun ia juga merupakan penduduk kota asli Bandung. Stella menjadi pilihan informan dikarenakan ia sering membuat konten dubbing dan reaction terkait album baru dan video clip EXO bersama dengan angota EXO-L lainnya, ia memulai dubbing konten EXO sejak ia masuk ke komunitas EXO-L yakni tahun 2012 Stella mulai memasuki komunitas tersebut karena kemauannya sendiri ia mengaku telah menyukai EXO sejak tahun 2011. Dari segi geografis, Stella juga mudah dijangkau dikarenakan lokasi kampusnya yang berkawasan di Depok dan kini tinggal di kost yang berkawasan dekat dengan kampus Universitas Indonesia.

\section{HASIL DAN PEMBAHASAN}

\section{Tahapan Celebrity Worship}

Celebrity worship dapat dikategorikan menjadi tiga jenis yaitu; entertainmentsocial, intense-personal, dan borderlinepathological. Ketiga jenis ini dapat juga dijadikan sebagai tingkatan celebrity worship dimulai dari tingkat normal yaitu entertainment-social dan tingkat yang berlebihan dan mendekati kriminal dikatakan borderline-pathological. Berikut hasil dari pernyataan-pernyataan informan:

\section{a. Entertainment-social}

Entertainment-social adalah tahap yang terjadi pada saat seorang individu merasa penting atau senang membicarakan sang idola dengan orang banyak, dan membicarakannya 
di depan orang-orang serta senang membicarakan perihal tentang sang idola dengan orang yang juga mengidolakannya, dengan mencerminkan dimensi kepribadian ektraversi seperti sosiabel, aktif, lincah dan berani. Pada tahap ini, didapati informasi yang berkaitan dengan kegiatan menghibur terkait EXO dan senang membicarakan idolanya ke orang lain atau orang yang mengidolakan juga. Dalam entertainment-social, mereka memiliki ketertarikan yang berada dalam level normal terhadap kehidupan idolanya. Alasan individu mencari informasi mengenai idolanya untuk confirm terhadap norma sosial saat membicarakan idola dengan orang lain maka individu secara tidak disadari membentuk standar normal dalam dirinya, hasilnya mereka akan mengetahui mana perilaku yang benar atau buruk untuk dilakukan (McCutcheon, 2004).

Berdasarkan hasil dari wawancara, informan satu mengungkapkan bahwa kegiatan yang menghiburnya karena euforia EXO ngeluarin album baru pasti semuanya serba baru dari segi konsep, style, dan rambut. Informan satu juga mengungkapkan beberapa kegiatan bersama EXO-L yang menyenangkan dan menghibur diri seperti gathering EXO-L karena dapat berkenalan dengan orangorang baru yang mengidolakan EXO, nonton musik video dan konser, dan di gathering ada kuis-kuis, games, doorprize. Informan satu mengidolakan Layzhang (EXO Mandarin) dan suka membicarakan Layzhang ke temantemannya lewat media sosial fanbase seperti Twitter dan Line Square.

Tidak seperti informan dua, informan dua mengungkapkan bahwa dirinya senang jika nonton EXO sampai goyang-goyang sendiri. Informan dua mengidolakan salah satu personil EXO yaitu D.O karena ganteng, dia sangat excited jika membicarakan EXO dengan sesama EXO-L dan untuk mengekspresikan kesenangannya, dirinya memakai media sosial instagram karena di instagram banyak foto-foto dan merasa puas.

Sama seperti informan dua, informan tiga juga mengungkapkan kegiatan yang membuat senang adalah nonton MV (music video), live perfomance dan variety show terkait EXO. Informan tiga mengidolakan personil EXO yang bernama D.O juga karena acting dan suaranya yang bagus. Dia suka membicarakan EXO dengan sesama EXO-L dan yang tidak menyukai EXO sehingga dia dapat mempengaruhi teman-temannya untuk menyukai EXO. Jika EXO comeback, dia langsung spam di akun media sosial dan membicarakan EXO lewat grup di line.

Berdasarkan pernyataan dari seluruh informan, maka dapat disimpulkan bahwa ketiga informan mengungkapkan kegiatan yang menghiburnya adalah dengan pengeluaran album baru EXO (comeback) karena selalu mengeluarkan konsep yang baru juga, mengikuti kegiatan gathering EXO-L, menonton MV (music video), live perfomance, variety show dan sering membicarakan EXO di media sosial seperti twitter, instagram dan grup line. Dengan adanya hasil wawancara tersebut, informan satu dalam tahap entertaiment social mengungkapkan bahwa dirinya merasa terhibur dengan EXO, namun tidak terlalu ekspresif saat mengutarakan terkait EXO. 
Namun, walaupun respon yang diberikan kurang ekspresif, informan satu memiliki pengetahuan yang jauh lebih dalam dibanding informan dua dan tiga yang sangat ekspresif namun pengetahuan mereka terkait EXO tidak sedalam informan satu.

Hal ini tentu sejalan dengan konsep entertainment-social karena entertainmentsocial merupakan tahap dimana seorang individu merasa penting atau senang membicarakan sang idola dengan orang banyak, dan membicarakannya di depan orang-orang serta senang membicarakan perihal tentang sang idola dengan orang yang juga mengidolakannya. Pada tahap ini, mereka memiliki ketertarikan yang berada dalam level normal terhadap kehidupan idolanya.

\section{b. Intense-personal}

Intense-personal merupakan tahap yang terjadi ketika seorang individu merasa adanya ikatan khusus dengan sang idola dan juga dapat merasakan apa yang dirasakan atau yang di alami sang idola tersebut, dengan mencerminkan dimensi kepribadian neurositisme seperti tertekan, emosional, cemas dan moody. Individu memiliki obsesi terhadap segala hal yang berhubungan dengan selebirti idolanya. Seorang penggemar K-Pop yang sudah berada ditahap ini pastinya tidak akan ragu untuk membeli album atau bahkan merchandise yang berhubungan dengan idolanya. Pada tahap ini mereka terindikasi memiliki beberapa ciri atau sifat neurotik (neurotic straits). Seseorang mungkin percaya bahwa dia memiliki koneksi personal yang kuat dengan idolanya, memperlakukan dan menganggap selebriti sebagai pasangannya. Perilaku yang termasuk dalam tahap ini adalah memikirkan selebriti dalam frekuensi secara terus menerus dalam kesehariannya (McCutcheon, 2004).

Dalam tahap ini terdapat jawaban yang berbeda dari masing-masing informan. Informan satu mengungkapkan bahwa tidak merasa ada ikatan khusus dengan Layzhang karena Layzhang dapat memotivasi orangorang untuk sukses. Dia juga hanya membeli merchandise tergantung kegunaannya saja tidak yang selalu berhubungan dengan EXO. Namun, dia sedih jika salah satu personil EXO sakit dan tidak tampil didepan layar. Pernyataan informan satu sangat berbeda dengan informan dua dan tiga karena mereka lebih memperlihatkan perilaku yang berlebihan.

Informan dua mengungkapkan EXO sangat berarti untuk kehidupannya karena dapat menjadi moodbooster bagi dirinya. Informan dua juga merasa ada ikatan khusus dengan salah satu personil EXO yaitu D.O dan menyatakan bahwa dia sudah sejiwa dengan D.O bahkan jika D.O sakit, dia ingin menemui dan merawatnya. Bahkan dia juga mengungkapkan dan menunjukkan perasaan sedih jika personil EXO sakit sampai tidak ingin makan dan menyendiri di kamar. Untuk merchandise terkait EXO, dia rutin membeli skincare merek Nature Republic karena EXO sebagai brand ambassador. Dia juga sering membeli merchandise seperti light stick, kaos, poster, bahkan sering mencetak sendiri foto-foto dan poster EXO.

Sama halnya dengan informan tiga 
yang menyatakan bahwa dia memiliki ikatan khusus dan selalu setia dengan EXO selalu membeli merchandise terkait EXO seperti baju, lightstick, jaket, tas, case, album, photo card, dan membuat foto dan poster yang kemudian di cetak sendiri. Dia juga mengungkapkan dan menunjukkan perasaan sedih jika personil EXO sakit dengan menyendiri di kamar.

Berdasarkan pernyataan dari seluruh informan, ketiga informan memiliki pernyataan yang berbeda. Informan satu merasa tidak memiliki ikatan khusus dengan personil EXO dan hanya membeli merchandise sesuai kegunaan saja dan menjual merchandise EXO jika tidak diperlukan lagi. Berbeda dengan pernyataan informan dua dan tiga, mereka memiliki ikatan khusus dengan personil EXO dan selalu membeli merchandise terkait EXO seperti baju, lightstick, jaket, tas, casing, album, photo card, dan membuat foto dan poster yang kemudian di cetak sendiri. Namun dari ketiga informan ikut sedih jika salah satu personil EXO sakit atau terkena musibah tetapi perilaku dari informan satu sangat berbeda dengan informan dua dan informan tiga karena informan dua dan informan tiga menunjukkan bahwa dirinya sedih dengan menyendiri di kamar bahkan tidak ingin makan.

Terlihat bahwa informan 1 tidak konsumtif dibanding informan 2 dan 3 . Namun, untuk setiap merchandise serta produkyang berkaitan dengan EXO, informan 1 lebih mengetahui strategi dalam pembelian merchandise, album, serta produk terkait
EXO. Bahkan informan 1 menunjukan tahap intense personal dengan membangun bisnis penjualan merchandise EXO, informan 1 tidak menyalurkan kegemarannya dengan konsumtif namun dengan peluang bisnis yang dia lakukan.

Hal ini tentu sejalan dengan konsep intense-personal karena intense-personal merupakan tahap dimana seorang individu merasa adanya ikatan khusus dengan sang idola dan juga dapat merasakan apa yang dirasakan atau yang di alami sang idola tersebut seperti tertekan, emosional, cemas dan moody. Dan seorang penggemar K-Pop yang sudah berada ditahap ini pastinya tidak akan ragu untuk membeli album atau bahkan merchandise yang berhubungan dengan idolanya.

Namun hal ini juga tidak sejalan dengan konsep intense-personal karena informan satu tidak konsumtif bahkan dia sering menjual koleksi merchandise EXO kepada teman-temannya.

\section{c. Borderline-pathological}

Borderline-pathological merupakan tahap yang terjadi dimana seorang individu memiliki fantasi atau khayalan yang membuatnya memiliki kedekatan khusus dengan sang idola dan mencerminkan dimensi kepribadian psikotisme seperti impulsif, anti sosial, dan egosentris. Individu juga akan rela melakukan apapun termasuk hal ilegal yang diperintahkan oleh selebriti idolanya. Tahap ini merupakan tingkatan paling tinggi atau parah dalam celebrity worship. Fans yang seperti ini tampak memiliki pemikiran yang tidak terkontrol dan menjadikan dirinya 
tidak rasional. Mereka juga memiliki obsesi terhadap detail kehidupan selebriti dan percaya bahwa mereka dapat berkomunikasi langsung dengan selebriti idolanya melalui kode rahasia, yang dia percayai hanya dia dan idolanya yang mengetahuinya. Kepercayaankepercayaan inilah yang dapat menyebakan kerugian dan perkembangan psikologis individu tersebut (McCutcheon, 2004).

Informan satu, dua dan tiga memiliki pernyataan yang sama tetapi dengan perilaku yang berbeda-beda. Informan satu mengungkapkan bahwa dia memiliki imajinasi seperti nikah dan berpacaran dengan salah satu personil EXO yaitu Layzhang. Informan satu pernah melakukan hal ilegal yang tidak terlalu berlebihan hanya membeli kaset EXO yang tidak original dan menyebarkan foto-foto privasi EXO kepada teman-temannya.

Berbeda dengan informan dua dan informan tiga, informan dua dan informan tiga mengungkapkan bahwa mereka pernah melakukan hal ilegal seperti nekat memasuki backstage EXO sampai diusir oleh satpam. Informan dua dan tiga memiliki imajinasi atau fantasi yang berbeda namun berlebihan. Informan dua mengungkapkan sering berkhayal tidur dan mandi bareng D.O serta pernah nekat foto selfie dan ngetag D.O agar seakan-akan ada di hidup D.O. Perilaku berlebihan juga dilakukan oleh informan tiga. Informan tiga mengungkapkan bahwa dia ingin menjadi istri D.O dan sering ngobrol dengan fotonya D.O setiap malam. Dia juga mengakui bahwa dirinya sedang nabung untuk pergi ke Korea demi EXO.
Berdasarkan pernyataan dari seluruh informan, ketiga informan memiliki pernyataan fantasi yang berbeda. Informan satu mengungkapkan hanya memiliki fantasi yang tidak berlebihan seperti menikah dan berpacaran dengan Layzhang dan menurutnya itu hal yang wajar sebagai fans serta hal ilegal yang pernah dilakuin adalah membeli kaset atau CD EXO yang tidak original dan menyebarkan foto-foto privasi EXO. Berbeda dengan jawaban informan dua dan tiga yang terlalu berlebihan, mereka mengungkapkan sering berkhayal tidur dan mandi bareng serta sering ngobrol dengan salah satu foto personil EXO. Hal ilegal yang dilakukan mereka adalah nekat memasuki backstage EXO sampai diusir satpam.

Terlihat bahwa informan satu tidak berlebihan dalam hal berfantasi, dia hanya memiliki fantasi menikah dengan salah satu personil EXO yang dia idolakan yaitu Layzhang namun hal ini berbeda dengan apa yang diungkapkan oleh informan dua dan tiga, mereka memiliki perilaku yang berlebihan dalam hal fantasi karena mereka berfantasi seperti tidur dan mandi bareng personil EXO yang di idolakan serta sering mengobrol dengan foto koleksinya.

Hal ini tentu saja sejalan dengan konsep borderline-pathological karena borderline-pathological merupakan tahap dimana seorang fans yang seperti ini tampak memiliki pemikiran yang tidak terkontrol dan menjadikan dirinya tidak rasional. Mereka juga memiliki obsesi terhadap detail kehidupan selebriti dan percaya bahwa mereka dapat berkomunikasi langsung 
dengan selebriti idolanya melalui kode rahasia, yang dia percayai hanya dia dan idolanya yang mengetahuinya.

\section{Faktor Celebrity Worship}

a. Usia

Banyak faktor yang menjadi latar belakang seseorang dalam melakukan pemujaan terhadap selebriti. Salah satu faktor tersebut adalah usia, puncak pemujaan terhadap selebriti berada pada remaja yang berusia 11 tahun hingga 17 tahun. Hal ini dikarenakan remaja yang berada dalam usia ini memiliki ketertarikan untuk membangun hubungan romantis dan memiliki pasangan untuk berkencan, ketika remaja dipengaruhi oleh norma aturan sosial disekitarnya maka akan mengharuskan seorang remaja memiliki ketertarikan romantis terhadap lawan jenis. Ada beberapa remaja yang tidak bisa membangun hubungan yang nyata dan memilih untuk menyukai seseorang selebriti (McCutcheon 2004 ).

Dalam hal ini, informan satu mengungkapkan bahwa rata-rata usia EXO-L yang paling muda ada pada jenjang SMP (11-13 tahun) dan yang paling tua ada diumur 35 tahun. Dalam perbedaan usia pada masingmasing fans, terdapat perbedaan perilaku juga dari masing-masing usia, informan 1 menyatakan bahwa karakter pemujaan di setiap usia memang berbeda. Di usia 18-20 atau setara kuliah, sikap atau perilakunya masih berlebihan dan yang sudah bekerja atau berkeluarga mengidolakan EXO hanya untuk hiburan semata. Di tingkat SMP (11-13 tahun) mengidolakan EXO sangat berlebihan bahkan sering berantem antar sesama EXO-L atau grup K-Pop lainnya.

Informan dua mengungkapkan di EXO-L rata-rata usianya ada pada tingkat SMA (14-17 tahun) sampai yang berusia 30 tahunan. Bahkan sampai membuat organisasi besar. Berbeda dengan informan satu, informan dua mennyatakan bahwa di dari masing-masing usia tersebut perilakunya sama. Masing-masing dari mereka memiliki excited yang sama.

Informan tiga mengungkapkan bahwa usia rata-rata EXO-L adalah kelahiran 90 tahunan ke bawah. Bahkan ada yang sudah memiliki keluarga atau anak tapi lebih banyak yang masih berkuliah sekitar 18-20 tahunan. Dari masing-masing usia, informan tiga menyatakan bahwa ada perbedaan perilaku dari setiap usia. Kelahiran sekitar tahun 2000an menunjukkan perilaku yang berlebihan seperti teriak-teriak tetapi yang sudah berusia dewasa perilakunya terbilang normal atau wajar.

Berdasarkan pernyataan dari seluruh informan, ketiga informan mengungkapkan usia EXO-L paling muda adalah anak SMP dan paling tua usia 35 tahun. Ada perbedaan perilaku pemujaan dari masing-masing usia yaitu jika yang berusia remaja memiliki perilaku yang berlebihan hingga melebihi batas wajar dan yang sudah dewasa, perilakunya lebih wajar dan menyukai EXO hanya sebatas menghibur.

Hal ini tidak sejalan dengan konsep pada faktor celebrity worship yaitu faktor usia karena dalam faktor usia, puncak pemujaan terhadap selebriti berada pada 
remaja yang berusia 11 tahun hingga 17 tahun. Namun, peneliti menemukan temuan baru bahwa faktor usia yang sudah semakin dewasa akan mempengaruhi perilaku pemujaan. Ketertarikan pada sosok selebriti ini akan berkurang seiring bertambahnya usia seseorang dan akan benar-benar hilang saat individu memasuki usia dewasa awal. Hal ini dikarenakan individu yang berada dalam usia perkembangan dewasa awal dinilai sudah lebih menajamkan identitasnya, mencapai tingkat autonomi dan mulai merubah ketertarikan yang mereka miliki. Dapat disimpulkan bahwa peneliti menemukan bentuk kemunduran atau penurunan perilaku celebrity worship karena sikap atau perilaku dari informan satu menunjukkan bahwa dirinya saat ini memiliki perilaku pemujaan yang tidak berlebihan tapi sangat mengenal atau mengetahui lebih detail mengenai EXO dibanding informan dua dan tiga. Informan satu lebih memanfaatkan koleksi merchandise miliknya untuk dijual ke temanteman yang mengidolakan EXO. Temuan tersebut dapat diperkuat dengan adanya pernyataan dari informan satu yaitu:

"Kalo masih kuliah kan masih pembentukan karakter juga jadi masih lebay. Cuma kalo yang udah tua pekerja atau udah berkeluarga ya ngefansnya cuma untuk ngehibur. Malah kalau seumuran aku sama anak SMA dan SMP sering berantem antar sesama fans atau grup kpop lain"

\section{b. Pendidikan}

Celebrity worship biasanya dilakukan oleh orang-orang dengan tingkat inteligensi yang rendah. Hal ini diungkapkan oleh informan satu. Informan satu mengungkapkan rata-rata pendidikan fans EXO sama rata. Biasanya yang lebih berada materinya (memiliki kekayaan) lebih berlebihan karena bisa beli semua barang-barang yang berkaitan dengan EXO. Informan dua juga mengungkapkan rata-rata pendidikan EXO-L adalah jenjang perkuliahan (McCutcheon 2004 ).

Berdasarkan pernyataan dari seluruh informan, ketiga informan mengungkapkan pendidikan para fans EXO sama rata atau di jenjang perkuliahan. Namun ada perbedaan materi, yang memiliki kekayaan bisa membeli semua barang-barang yang berkaitan dengan EXO.

Hal ini tidak sejalan dengan konsep pada faktor celebrity worship yaitu faktor pendidikan karena dalam faktor pendidikan, perilaku celebrity worship dilakukan oleh orang-orang yang memiliki tingkat inteligensi rendah. Dalam hal ini, peneliti menemukan beberapa orang yang memiliki sikap pemujaan namun memiliki pendidikan yang tinggi bahkan jika mereka memiliki kekayaan akan merelakan seluruh hartanya hanya untuk EXO seperti membeli barangbarang terkait EXO dengan harga yang sangat tinggi.

\section{c. Keterampilan sosial}

Pada faktor keterampilan sosial, pemujaan menjadi faktor penghalang keterampilan seseorang dalam melakukan hal sesuai dengan kemampuannya hal ini terjadi pada orang-orang dengan keterampilan sosial yang buruk dan melihat bahwa celebrity 
worship merupakan pengisi kekosongan yang terjadi dalam hubungan yang nyata (McCutcheon, 2004). Hasil temuan dari peneliti yakni bahwa keterampilan sosial yang dimiliki para fans EXO yang berperilaku celebrity worship tak selamanya memiliki keterampilan sosial yang buruk, bahkan para fans EXO mereka memiliki keahlian tersendiri namun dikesampingkan karena sikap pemujaan yang terlalu berlebihan. Dalam sebuah konsep celebrity worship juga dikatakan sebagai pengisi kekosongan yang nyata, namun dari hasil penelitian bersama dengan informan membuktikan bahwa kegemaran terhadap EXO terjadi karena adanya ketertarikan para informan (baik tertarik dengan penampilan atau musik EXO) namun tak berarti kegemaran terhadap EXO menjadi pengisi kekosongan, melainkan membuat para fans merasa memiliki pekerjaan lain selain kegiatan yang lebih berharga.

d. Jenis Kelamin:

Laki-laki dan perempuan dapat menyukai idola dengan konteks yang berbeda namun intensitas untuk menyukai idola biasanya lebih tinggi di kaum perempuan (McCutcheon 2004). Pada faktor ini informan mengungkapkan bahwa perempuan lebih dominan menjadi anggota EXO-L dibanding laki-laki. Tingkat pemujaan antara laki-laki dengan perempuan kerap berbeda. Namun, pemaparan dari salah satu informan menjelaskan bahwa anggota EXO-L pria ratarata bergaya layaknya queer. Dari pemaparan informan menjelaskan bahwa jenis kelamin celebrity worship terhadap EXO lebih dominan kepada perempuan. Seperti konsep yang diberikan oleh McCutcheon (2004) bahwa intensitas pemujaan perempuan lebih tinggi dibanding perempuan. Hal ini dibuktikan dari pernyataan informan yang menjelaskan bahwa perempuan selalu lebih dominan menyukai EXO serta sering melakukan hal-hal di luar batas kewajaran dibanding seorang pria.

\section{Aspek Celebrity Worship}

a. Aspek Religiusitas

Glock dan Stark (dalam Ancok \& Suroso, 2004) menjelaskan religiusitas adalah keseluruhan dari fungsi manusia yang meliputi keyakinan, perasaan, dan perilaku yang diarahkan secara sungguh-sungguh dan sadar pada ajaran agamanya. Aspek religiusitas pada faktor ini berhubungan dengan tingkatan religiusitas individu. Sesuai dengan bukti dari pernyataan informan bahwa pemujaan yang dilakukan hanya sebatas melalaikan ibadah, namun tak sampai merubah keyakinan mereka hanya untuk EXO, maka konsep yang menyatakan kalau celebrity worship dapat mengubah keyakninan tak selamanya seperti pemaparan dari konsep tersebut, di mana sikap pemujaan hanya menyampingkan kepercayaan namun tak merubah kepercayaan mereka sepenuhnya.

\section{b. Aspek Body Image}

Berdasarkan penelitian yang dilakukan oleh Maltby et al., (2005) bahwa celebrity worship juga dipengaruhi oleh body image. Seorang selebriti yang memiliki tubuh ideal biasanya menjadi tolak ukur bagi seorang penggemar untuk 
membentuk tubuh yang ideal seperti artis idolanya. Dari setiap pemaparan informan, terlihat bahwa kegemaran para EXO-L Bandung dari segi body image mereka rela melakukan perubahan khususnya dalam hal penampilan dengan boyband EXO. Sesuai pemaparan dari Maltby et al (2015) bahwa seorang selebriti yang memiliki tubuh ideal biasanya menjadi tolak ukur bagi seorang penggemar untuk membentuk tubuh yang ideal seperti artis idolanya. Namun berbeda dengan para informan yang justru mengubah penampulan dan memiliki tubuh ideal untuk dapat mengambil perhatian para selebriti yang mereka gemari. Di mana konsel yang disebutkan oleh Maltby ini hanya menjelaskan bahwa seseorang mengubah penampilan seperti selebriti yang mereka sukai, hal ini juga diterapkan oleh informan seperti membeli baju dan fashion brand dari EXO namun mereka lebih dominan mengubah penampilan (body image) untuk mengambil perhatian para personil EXO.

\section{c. Aspek Kepribadian}

Dalam aspek kepribadian, kepribadian disini diartikan sebagai perilaku individu atau penggemar yang terpengaruh oleh idolanya (Swami et al., 2015). Hal ini ditujukan dari hasil jawaban yang dipaparkan oleh informan dimana mereka menjelaskan bahwa kepribadian mereka kian berubah semenjak menggemari EXO. Dari berbagai pernyataan dari informan menjelaskan bahwa kepribadian mereka berubah semenjak menyukai EXO. MenurutSwametal.(2015)bahwakepribadian seseorang terpengaruh kepada idola yang mereka puja. Konsep yang dikatakan oleh
Swam terbukti dari hasil pernyataan informan bahwa kepribadian mereka menjadi berubah dikarenakan kegemaran mereka terhadap EXO. Tentu EXO mempengaruhi kepribadian informan menjadi lebih terbuka, mereka juga mengaku kalau menemukan jati diri setelah menyukai EXO.

\section{KESIMPULAN}

Dari penelitian yang telah dilakukan terdapat beberapa kesimpulan yaitu sebagai berikut:

1. Dalam tahapan celebrity worship khususnya entertainment-social, ketiga informan senang membicarakan EXO kepada orang-orang yang menyukai EXO juga. Ketiga informan mengungkapkan kegiatan yang dapat menghibur mereka dengan menonton MV (Music Video), live performance, pengeluaran album baru EXO, dan variety show terkait EXO.

2. Di tahapan celebrity worship khususnya intense-personal, ketiga informan memi -liki perilaku yang berbeda. Informan 1 tidak merasa ada ikatan khusus dengan EXO dan membeli merchandise terkait EXO dari kegunaannya saja, tidak seperti informan 2 dan 3 yang merasa punya ikatan khusus atau batin terhadap EXO serta selalu membeli merchandisemerchandise terbaru terkait EXO.

3. Dalam tahapan tertinggi di tahapan celebrity worship yaitu borderlinepathological, ketiga informan memiliki pernyataan yang sama tetapi dengan 
perilaku yang berbeda-beda seperti hal ilegal dan kegiatan fantasi yang dilakukan.

4. Pada faktor celebrity worship khususnya faktor usia, ketiga informan menyatakan mayoritas usia dalam EXO-L Bandung adalah tahun kelahiran 90-an. Ada perbedaan dari masing-masing usia, jika yang berusia lebih muda memiliki fanatik luar biasa dan yang berusia lebih tua lebih dewasa.

5. Di dalam faktor celebrity worship khususnya pendidikan, ketiga informan menyatakan bahwa rata-rata pendidikan EXO-L sama rata atau berada dijenjang perkuliahan dan yang memiliki materi (kekayaan), akan membeli atau mengikuti kegiatan EXO.

6. Dalam faktor celebrity worship yaitu keterampilan sosial, ketiga informan memaparkan bahwa mereka mengesampingkan hobi demi melakukan pemujaan terhadap EXO yang dimana dengan adanya kehadiran EXO mereka menyatakan kalau hobi mereka jadi terlupakan dengan menghabiskan waktu untuk EXO semata.

7. Pada faktor celebrity worship yaitu jenis kelamin, dalam EXO-L didominasi oleh jenis kelamin perempuan yang memiliki perilaku pemujaan diluar batas kewajaran dibandingkan laki-laki.

8. Terdapat aspek celebrity worship yaitu religiusitas, ketiga informan tidak menyampingkan agama demi EXO namun informan 3 sering melalaikan ibadah demi menonton live streaming.

9. Dalamaspekcelebrityworshipkhususnya body image, ketiga informan menyatakan bahwa personil EXO menjadi tolak ukur mereka dalam mencari pasangan hidup dan menentukan pria yang ideal. Kedua dari tiga informan juga menyatakan mereka rela mengubah penampilannya agar menarik perhatian EXO.

10. Pada aspek celebrity worship yaitu kepribadian, ketiga informan menjelaskan bahwa kepribadian mereka berubah semenjak mengidolakan EXO. Mereka menyatakan kepribadiannya berubah menjadi lebih ekspresif dan tidak tahu malu.

11. Berdasarkan hasil penelitian, peneliti menemukan temuan baru yaitu bentuk kemunduran atau penurunan perilaku celebrity worship, dilihat dari usia remaja yang memperlihatkan perilaku pemujaan berlebihan jika mengidolakan artis atau selebriti dan adanya penurunan perilaku pemujaan ketika sudah dewasa. Sikap orang dewasa lebih wajar dan tidak berlebihan.

\section{SARAN}

Dari penelitian yang telah dilakukan tedapat saran praktis yang ditujukan untuk perkembangan penelitian lebih lanjut, saran praktis yang ditujukan untuk perkembangan pemujaan dari komunitas EXO-L Bandung, dan saran masalah sosial yang ditujukan.

\section{Saran Akademis}


Penelitian selanjutnya dapat lebih berfokus kepada siklus sikap celebrity worship dimana penelitian terkait tahapan lanjutan dari sikap pemujaan ini belum ada penjabaran serta teori yang menyangkut terkait siklus tahap lanjutan perilaku cebelrity worship dan diharapkan untuk meneliti terkait penurunan sikap celebrity worhsip berdasarkan faktor usia.

\section{Saran Praktis}

Komunitas EXO-L Bandung seharusnya mengadakan kegiatan positif demi membentuk perilaku celebrity worship sewajarnya yakni untuk menghindari terjadi tingkah pemujaan yang melewati batas.

\section{Saran Sosial}

Dalam perilaku celebrity worship yang dilakukan oleh komunitas EXO-L Bandung diharapkan penelitian selanjutnya dapat memberikan gambaran terkait bagaimana setiap perilaku dari anggota EXO-L Bandung kepada masyarakat luas terkait kegiatan serta perilaku, agar masyarakat luas dapat memahami apa yang selama ini dilakukan oleh komunitas fandom salah satunya seperti EXO-L Bandung.

\section{DAFTAR PUSTAKA}

Buku (Versi Cetak) Ardianto, Elvinaro, Q-Anees, 2007. Filsafat Ilmu Komunikasi. Bandung: Simbiosa Rekama Media.

Basrowi dan Suwandi. 2008. Memahami Penelitian Kualitatif. Jakarta: Rineka Cipta
Bungin, M. Burhan. 2007. Penelitian Kualitatif: Komunikasi, Ekonomi, Kebijakan Publik, dan Ilmu Sosial Lainnya. Jakarta: Kencana Prenada Media Group.

Camic, P. M, Rhodes, J. E., \& \& Yardley, L. (Ed.). (2003). Qualitative research in psychology: Expanding perspectives in methodology and design. Washington, DC: American Psychological Association.

Creswell, John W. (2014). Research Design: Qualitative, Quantitative, and Mixed Methods Approaches. London: Sage.

Daymon, Christine and Immy Holloway. (2011). Qualitative Research Methods in Public Relations and Marketing Communication. Second Edition. New York: Routledge.

Deddy Mulyana. (2003). Metodologi Penelitian Kualitatif. Bandung: PT. Remaja Rosdakarya

Hennink, Monique, Inge Hurter, and Ajay Bailey. (2011). Qualitative Research Method. California: Sage Publication

John, Little \& Foss (2009). Teori Komunikasi, 9th ed. Jakarta: Salemba Humanika.

Levy (2015), Celebrity Worship Concept, hal. 47, Florida, USA

McCutcheon, Lynn (2004), Celebrity Worshippers: Inside the Minds of Stargazers. PublishAmerica.

Moleong, L. J. (2012). Metodologi Penelitian Kualitatif. Bandung, Indonesia: PT REMAJA ROSDAKARYA.

Smith, J.A., P. Flower and M. Larkin (2009). Interpretative Phenomenological Analysis: Theory, Method and Research. London: Sagev.

Soenarno (2002). Kekuatan Komunitas Sebagai Pilar Pembangunan Nasional. Jakarta. 
Sugiyono (2010). Metode Penelitian Pendidikan Pendekatan Kuantitatif, kualitatif, dan R\&D. Bandung: Alfabeta.

Wenger, E., R. A. McDermott, et al. (2002). Cultivating communities of practice: a guide to managing knowledge. Boston, Mass., Harvard Business School Press.

Artikel Jurnal Online Craig, T. Robert (2016). Jurnal: Traditions of Communication Theory. https://onlinelibrary.wiley. com/doi/abs/10.1002/9781118766804. wbiect119

Maltby, J., Giles, D.C., Barber, L., dan McCutcheon, L.E. (2005). IntensePersonal Celebrity Worship and Body Image: Evidence of A Link Among Female Adolescents. British Journal of Healt Psychology vol 10.

Kuswarno (2007). Jurnal: Tradisi Fenomenologi pada Penelitian Kualitatif. Dikutip dari http://jurnal.unpad.ac.id/ sosiohumaniora/article/view/5384

Rayner, Wall (2004). Media Studies: The Essential Resource. Dikutip dari http://services.searchtabnew.com//crx/ search.php?k=leby $\% 20$ celebrity $\% 20$ wo rship\&action $=\mathrm{ds} \&$ guid $=3 \mathrm{c} 4 \mathrm{e} 2 \mathrm{df} 6$ 199b-a3b8-9311-9b259ed4ab4a

Rojek, C. (2004). Celebriy. Reaktion Books. Dikutip dari https://www.goodreads. com/book/show/647794.Celebrity

Besty Gooch, "The Communication ofFan Culture: The Impact of New Media on Science Fiction and Fantasy Fandom", Thesis, (Georgia Institute of Technology, 2008), https://smartech.gatech.edu/bitstream/ handle/1853/21818/gooch_betsy_r_20 805 ro.pdf
Sendjaja, D. (2015). Modul Teori Komunikasi Kelompok. Dikutip dari http:/webcache. googleusercontent.com/search?q=cach e:NNftr9uto4gJ:ravii.st aff.gunadarma. ac.id/Downloads/files/54297/ Teori\%2Bkom $=$ kelompok.doc $+\&$ $\mathrm{cd}=17 \& \mathrm{hl}=\mathrm{en} \& \mathrm{ct}=\mathrm{clnk} \& \mathrm{gl}=\mathrm{id}$

Sheridan, L., North, A., Maltby,J., \& Gillett, R. (2007). Celebrity worship, addiction and criminality. Psychology, Crime \& Law, 13(6), 559-571.

Swami, et al. (2011) Jurnal: Celebrity Worship Among University Students in Malaysia, A Methodological Contribution to the Celebrity Attitude Scale. https://www.researchgate.net/ publication/232451541_Celebrity_ Worship_Am ong_University Students_in_Malaysia_A Methodological Contribution to $t$ he_Celebrity_Attitude_Scale

Artikel Surat Kabar Online Harsadakara. (2018). Ngeri! 5 Artis Indonesia Ini Hampir Dapat Surat Berisi Darah dari Fans 'Fanatik' K-Pop. Dikutip dari https:// www.boombastis.com/artis indonesiadiserang-sasaeng/132396

Hidayati, L. (2018). Disumpahi Mati, Anji Peringatkan Fans EXO di Indonesia. Dikutip dari: https://celebrity.okezone. com/read/2018/03/31/205/1880455/ disumpahi-mati-anji-peringatkan-fansexo-di-indonesia

Pemita, D. (2017). Bukan Army, Ternyata EXO-L Fans Paling Loyal. Dikutip dari https://www.liputan6.com/showbiz/ $\mathrm{read} / 3007125 /$ bukan-army-ternyataexo-1- fans-paling-loyal. 